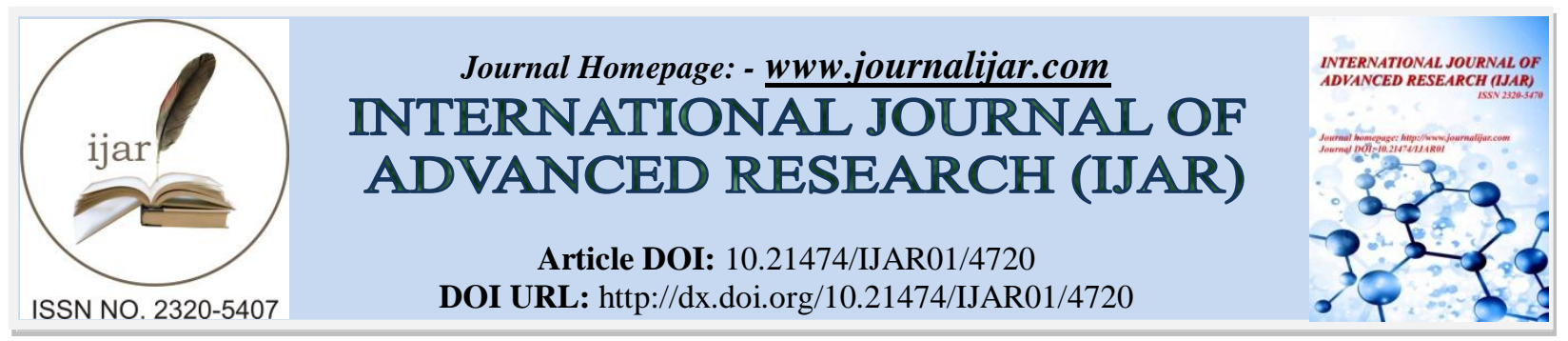

RESEARCH ARTICLE

\title{
FREQUENCY OF ANEMIA IN WOMEN REPORTING FORTIS HOSPITAL IN KALYAN CITY, THANE.
}

Department of Mathematics and Statistics, L. D. Sonawane College, Kalyan 421301, Maharashtra, India.

\section{Manuscript Info}

Manuscript History

Received: 3 May 2017

Final Accepted: 5 June 2017

Published: July 2017

Key words:-

Anemia, Various levels of Anemia,

Hospital based study.

\section{Abstract}

Objectives: To document the frequency of anemia in all patients specifically women who reported to veterinary pathology lab in Fortis hospital in Kalyan city and to find the frequency of various grades of anemia in male and female patients.

Methodology: This hospital based study was conducted in veterinary pathology lab in Fortis hospital in Kalyan city. A total of 4834 "full blood count" reports of 3022 male patients and 1812 female patients were reviewed for this study which were performed from $1^{\text {st }}$ September 2016 to $30^{\text {th }}$ November 2016. Haemoglobin level $<13 \mathrm{mg} / \mathrm{dL}$ for males and $<12 \mathrm{mg} / \mathrm{dL}$ for females was considered as anemic.

Results: Out of total 4834 patients, $62.20 \%(\mathrm{n}=3007)$ were found to be anemic while $37.80 \%(\mathrm{n}=1827)$ patients had normal haemoglobin levels. There were $1712(56.65 \%)$ male and 1295 (71.47\%) female which were found to be anemic. Moderate anemia and severe anemia were more common in female patients as compared to male patients (34.83\% Vs. $30.26 \%)$ and (9.80\% Vs. $8.99 \%)$ respectively while mild anemia were more common in male patients $(60.75 \%)$ than female patients $(55.37 \%)$. Agewise distribution of anemic patients was also given in this research paper.

Conclusion: Percentage of anemia was high in female patients compared to male patients reported to veterinary pathology lab in Fortis hospital in Kalyan city.

Copy Right, IJAR, 2017,. All rights reserved.

\section{Introduction:-}

Anemia is a condition characterized by a reduction in the red blood cell count or in the concentration of hemoglobin. Anemia is not a disease; it is a manifestation of various diseases and pathologic conditions.

Blood consists of cellular elements and plasma. The cellular elements include erythrocytes, or red blood cells; leucocytes, or white blood cells; and platelets. Red blood cells are the most numerous cells in the blood; approximately 20 billion of them circulate in the blood of an adult. They are required to transport oxygen to the tissues and organs of the body. Red blood cells contain hemoglobin, an iron-containing protein that acts in the transportation of oxygen to the tissues and carbon dioxide from the tissues. When the concentrations of hemoglobin or red blood cells in the blood are reduced to below normal, anemia is developed.

Corresponding Author:- Yogita Sanas.

Address:- Department of Mathematics and Statistics, L. D. Sonawane College, Kalyan 421301,

Maharashtra, India. 
Anemia is recognised as a major public health problem throughout the world, affecting about half of the women and young children in developing countries. Early detection of anemia could help prevent some problems of child development and many severe complications of pregnancy and delivery. Anemia increases morbidity from infectious diseases because important immune mechanisms, especially cellular immunity, are adversely affected. Patients with anemia usually complain of decreased work tolerance, fatigue, shortness of breath, palpitations, and other signs of adjustments of the heart and lungs to anemia.

In India various studies have been performed on different segments of populations covering different aspect of this important public health problem. The objectives of this study were to document frequency of anemia in all patients who presented to out-patient and/or in-patient in veterinary pathology lab in Fortis hospital in Kalyan city and to find the frequency of various grades of anemia in male and female patients.

\section{Methodology:-}

\section{Study Design and Study Setting:-}

A hospital based study was conducted in veterinary pathology lab in Fortis hospital in Kalyan city. Fortis Healthcare Limited is a leading integrated healthcare delivery service provider in India. The healthcare verticals of the company primarily comprise hospitals, diagnostics and day care specialty facilities. Currently, the company operates its healthcare delivery services in India, Dubai, Mauritius and Sri Lanka with 54 healthcare facilities (including projects under development), approximately 10,000 potential beds and 314 diagnostic centres.

\section{Study Sample and Data Collection:-}

The inclusion criteria was all " full blood count " reports of patients presented to out patient and in patient in Fortis hospital, Kalyan from $1^{\text {st }}$ September 2016 to $30^{\text {th }}$ November 2016.

A total of 4834 reports were reviewed for this study. Among them 3022 patients were males and 1812 patients were females.

The reference ranges for hemoglobin concentration categories used in this study were according to levels recommended by World Health Organisation. Hemoglobin level above $13 \mathrm{mg} / \mathrm{dL}$ for males and above $12 \mathrm{mg} / \mathrm{dL}$ for females was considered as normal. Any level below these values was considered as anemic. Hemoglobin between 10-12.9 mg/dL for males and between 10-11.9 mg/dL for females was categorized as 'Mild Anemia'. For both genders, $\mathrm{Hb}$ level between 8-9.9 mg/dL was referred to as 'Moderate Anemia' and below $8 \mathrm{mg} / \mathrm{dL}$ was considered as severe anemia.

\section{Data Analysis:-}

Data was recorded and analyzed using Statistical Package for Social Sciences v20.0. Results were recorded as frequencies, means \pm standard deviations $(\mathrm{SD})$ and $\mathrm{p}$-values.

\section{Results:-}

There were about 4834 reports of patients which were included in the study. $37.80 \%(\mathrm{n}=1827)$ of all patients had normal haemoglobin level while 62. 20\% ( $n=3007)$ were anemic according to laboratory result of full blood count. Table 1 shows various statistical measures of anemia in male and female populations.

Table1:- Various Statistical Measures of Haemoglobin in both genders

\begin{tabular}{|l|l|l|l|l|l|l|l|}
\hline Gender & Anemic & Normal & Total & Mean & SD & Range & p-value \\
\hline Male & $1712(56.65 \%)$ & $1310(43.35 \%)$ & 3022 & 12.18 & 2.68 & 18 & $2.75823 \mathrm{E}-$ \\
\hline Female & $1295(71.47 \%)$ & $517(28.53 \%$ & 1812 & 10.71 & 1.89 & 12 & 24 \\
\hline Total & $1827(37.80 \%)$ & $3007(62.20 \%)$ & 4834 & & & & \\
\hline
\end{tabular}

The mean difference is significant at the P.value $\leq 0.05$

In our study, hemoglobin levels above $13 \mathrm{gm} / \mathrm{dl}$ (for males) and above $12 \mathrm{gm} / \mathrm{dL}$ (for females) was takes as 'normal' while levels below this were labeled as 'anemic'. There were 1712 male patients (56.65\%) and 1295 female patients $(71.47 \%)$ which were anemic. There was a significant difference between gender and presence/absence of anemia in study populations. 
Moderate anemia and severe anemia were more common in female patients as compared to male patients (34.83\% Vs. $30.26 \%)$ and $(9.80 \%$ Vs. $8.99 \%)$ respectively while mild anemia were more common in male patients $(60.75 \%)$ than female patients $(55.37 \%)$. Table 2 shows comparison of various grades of anemia in both genders.

Table2:- Various Grades of Anemia in both genders

\begin{tabular}{|l|l|l|}
\hline Anemia & Male & Female \\
\hline $\begin{array}{l}\text { Mild Anemia } \\
(\mathbf{1 0 - 1 2 . 9 ~} \mathbf{~ m g / d L )}\end{array}$ & $1040(60.75 \%)$ & $717(55.37 \%)$ \\
\hline $\begin{array}{l}\text { Moderate Anemia } \\
(\mathbf{8}-9.9 \text { mg/dL) }\end{array}$ & $518(30.26 \%)$ & $451(34.83 \%)$ \\
\hline $\begin{array}{l}\text { Severe Anemia } \\
(<\mathbf{8} \mathbf{~ m g / d L )}\end{array}$ & $154(8.99 \%)$ & $127(9.80 \%)$ \\
\hline Total & 1712 & 1295 \\
\hline
\end{tabular}

Figure1:- Bar chart showing Various Grades of Anemia in both genders

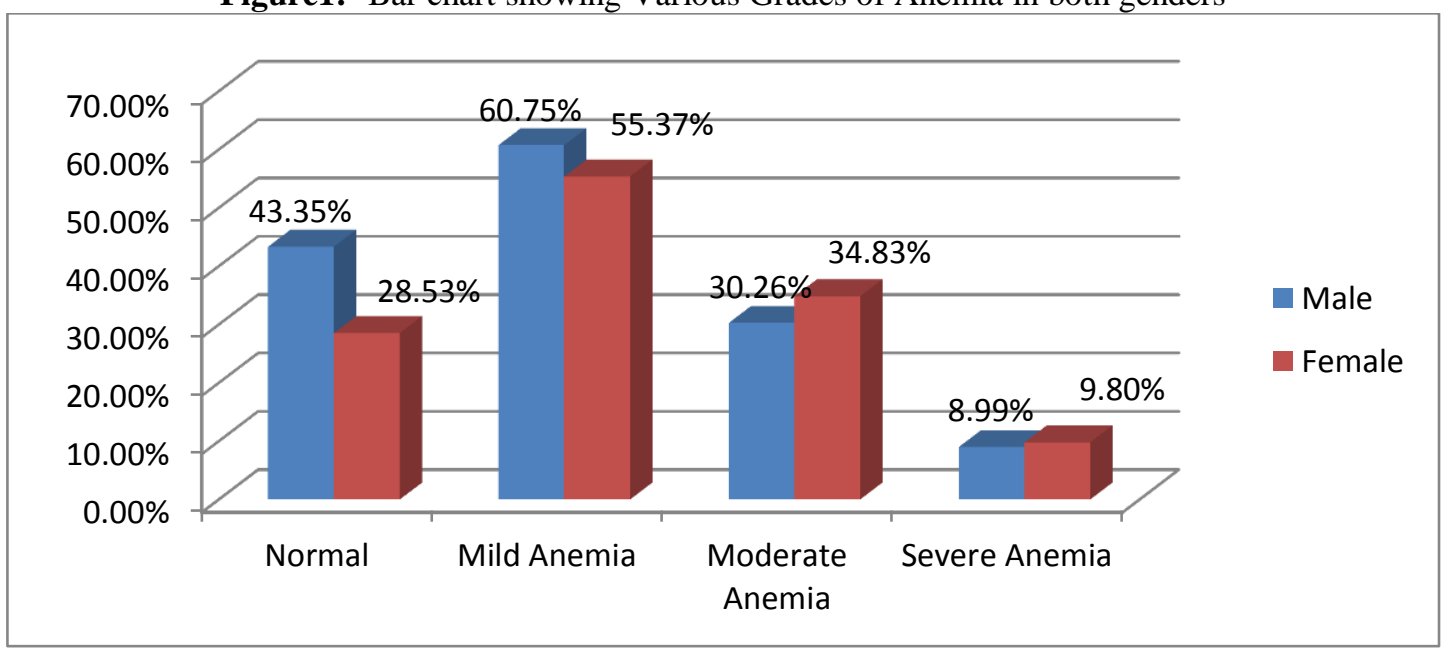

Table3:- Agewise distribution of Anemic patients in both genders

\begin{tabular}{|l|l|l|}
\hline Age & Male & Female \\
\hline Below 20 & $59(3.44 \%)$ & $49(3.78 \%)$ \\
\hline $\mathbf{2 0 - 2 9}$ & $100(5.84 \%)$ & $139(10.73 \%)$ \\
\hline $\mathbf{3 0 - 3 9}$ & $126(7.36 \%)$ & $113(8.73 \%)$ \\
\hline $\mathbf{4 0 - 4 9}$ & $164(9.58 \%)$ & $199(15.37 \%)$ \\
\hline $\mathbf{5 0} \&$ above & $1263(73.77 \%)$ & $795(61.39 \%)$ \\
\hline Total & 1712 & 1295 \\
\hline
\end{tabular}

Table 3 represent agewise distribution of anemic patients which shows that females in different age group from below 20 to 40-49 were more anemic than males in that age group.

\section{Discussion:-}

Anemia is widely prevalent in India and its prevalence in children and pregnant females has been reported in various WHO reports as well as in local literature. According to NFHS-3 (2005-06) in India, $55 \%$ of women and $24 \%$ of men whose haemoglobin level was tested were found to be anemic. $39 \%$ of women are mildly anemic, $16 \%$ are moderately anemic, and $2 \%$ are severly anemic. Although the prevalence of anemia varies considerably among the states, it is widespread in every Indian state. The prevalence of anemia for both women and men is very high in all the states in the east region, especially in Jharkhand and Bihar where more than two -thirds women and one-third of men are anemic. Other states with particularly high levels of anemia are Tripura and Assam (for both men and women), Andhra Pradesh and Sikkim (for men ), and Meghalaya (for women). Kerala, Manipur, Goa and Punjab have the lowest prevalence of anemia for both women and men. Even in these states, however, more than one-third of women are anemic. 
According to NFHS4 (2015-16) in Maharashtra, 48\% of all women age 15-49 years are anemic and $17.6 \%$ of all men age 15-49 years are anemic. In thane district $48.4 \%$ of all women and $17.1 \%$ of all men age $15-49$ years are anemic. In this study also I found a very high percentage of anemia in female patients in addition to above mentioned information.

Anemia and iron deficiency lead to substantial physical productivity losses in adults. Iron deficiency during pregnancy is associated with maternal mortality, preterm labour, low birth-weight, and infant mortality. In children, iron deficiency affects cognitive and motor development and increases susceptibility to infections. The high frequency of anemia found in female population in this study (71.47\%) depicts that it is not only the pregnant females which are at increased risk of anemia but the female population overall suffers from anemia. Iron supplements before, during and after pregnancy should be encouraged/prescribed to all females to avoid the ill effects of anaemia in later stages of life 21.

\section{Limitations of Study:-}

There were a number of limitations in this study. This was a hospital based study and only included reports of patients who were advised 'full blood count' investigation. This refers to the population which are at high-risk to develop anemia. There was no correlation with age of patients, presenting complaints, clinical presentation, socioeconomic status, education level, BMI, dietary habits and any history of blood loss or blood transfusion.

\section{Conclusion:-}

It was concluded in this study that there is a very high frequency of anemia in patients presenting to veterinary pathology lab in Fortis hospital, Kalyan. The percentage was higher amongst female patients compared to male patients. Even after excluding the 2 high risk groups' i.e. pregnant females and infants, a high frequency rate is very alarming and effective strategies need to be adopted to prevent this public health problem. Further large-scale, community based research is needed to precisely investigate the prevalence of anemia in our population.

\section{References:-}

1. Akhter MS, Akhter MW, Tajammul A, Malik M, Nighat U, Akhter NS. Profile of anemic patients attending a tertiary care hospital in Pakistan, study of 650 cases. Medical Channel 1997; 3(2):9-12

2. Khan MT, Akhtar T, Niazi M. Prevalence of anemia among university of Peshawar students. J Postgrad Med Inst 2010; 24(4): 265-269.

3. Kotecha P.V., "Nutritional anemia in young children with focus on Asia and India," Indian Journal of Community Medicine, vol. 36, no. 1, pp. 8-16, 2011. View at Publisher · View at Google Scholar · View at Scopus

4. Pappas G, Akhtar T, Peter JG, Wilbur CH, Khan AQ. Health Status of the Pakistani Population: a health profile and comparison with the United States. Am J Public Health 2001;91:93-8.

5. Paracha PI, Hameed A, Simon J, Jamil A, Nawab G. Prevalence of anemia in semiurban areas of Peshawar, Pakistan: A challenge for health professionals and policy makers. J Pak Med Assoc 1997;47(2):49-53

6. Patel S, Shah M, Patel J, Kumar N. Iron deficiency anemia in moderate to severely anemic patients. Gujarat Medical Journal 2009; 4(2):15-19

7. WHO, UNICEF, and UNU, Iron Deficiency Anaemia: Assessment, Prevention and Control, A Guide for Programme Managers, WHO, UNICEF, UNU, Geneva, Switzerland, 2001, http://www.who.int/nutrition/publications/micronutrients/anaemia_iron_deficiency/WHO_NHD_01.3/en/ index.html.

8. WHO, Haemoglobin Concentrations for the Diagnosis of Anaemia and Assessment of Severity, WHO, Geneva, Switzerland, 2011, http://www.who.int/vmnis/indicators/haemoglobin/en/. 